\title{
$\begin{array}{llllllll}\mathbf{A} & \mathbf{R} & \mathbf{T} & \mathbf{Y} & \mathbf{K} & \mathbf{U} & \mathbf{L} & \mathbf{Y}\end{array}$
}

Collectanea Theologica

88(2018) nr 1

ZDZISŁAW ŻYWICA, OLSZTYN

\section{ROZUMNA SŁUŻBA A ODNOWIONY UMYSŁ W ŚWIETLE RZ 12,1-2}

W Liście do Rzymian Paweł bardzo obszernie omawia kwestie kerygmatyczne, w mniejszym zaś zakresie poświęca uwagę zagadnieniom parakletycznym. ${ }^{1}$ Nie oznacza to jednak, że część poświęconą paraklezie uważa za mniej istotną. Przeciwnie, w całym swym nauczaniu epistolarnym wyraźnie traktuje paraklezę jako konsekwencję kerygmatu, jego drugą stronę. Dlatego też każdy jego list zawiera kerygmat i paraklezę oraz $\mathrm{z}$ równie żarliwym zaangażowaniem i głębokim przekonaniem zachęca zarówno do przyjęcia przedłożonego przesłania kerygmatycznego, jak i dawania żywego świadectwa jego przyjęcia w codziennej egzystencji: w sposobie myślenia, języku i stylu życia. Co więcej, w wielu wypowiedziach, szczególnie w 1 i 2 Liście do Koryntian oraz w Liście do Galatów, traktuje świadectwo egzystencjalne jako kryterium autentyczności przyjęcia i wyznawania wiary.

W charakterystyczny dla siebie sposób, ów ścisły związek obu części jednej Ewangelii, apostoł podkreśla w Rz 12,1 przez zastosowanie zwrotu: parakalō oun - ,zachęcam więc", którym rozpoczyna

1 Punktem wyjścia do prowadzonych analiz egzegetycznych jest kompozycja listu zaproponowana przez J.-N. A 1 e $t \mathrm{t}$ i, List do Rzymian w: W.R. F a r m e r (red.), Międzynarodowy Komentarz do Pisma Świętego. Komentarz katolicki i ekumeniczny na XXI wiek, tłum. M. Ż u r o w s k a, Wydawnictwo „Verbinum”, Warszawa 2000, s. 1411n. Wygląda ona następująco: Praescriptum (1,1-7); Exordium (1,8-17) kończące się Propositio do całego listu (1,16-17); Probatio składające się z trzech sekcji tematycznych: 1) Żyda i Greka usprawiedliwia jedynie wiara (1,18-4,25); 2) Nowe życie i nadzieja ochrzczonych (5-8); 3) Izrael i poganie: przyszłość Izraela (9-11); Zachęty (12,1-15,13); Peroratio (15,14-21); Informacje i pozdrowienia końcowe $(15,22-33+16,1-27)$ z Postscriptum w 15,33. 
sekcję zachęt 12,1 - 15,13. ${ }^{2}$ Jej propositio (12,1-2), dzięki zastosowaniu partykuły oun, czyni kerygmatyczną kwintesencją i parakletyczną konsekwencją doktryny wyłożonej w $1,18-11,36 .{ }^{3}$ Jego lektura rodzi

2 Wskazuje na to zastosowana partykuła oun („więc”, ,zatem”); por. H. S c h 1 i e r, Der Römerbrief. Herders Theologischer Kommentar zum Neuen Testament (Sonderausgabe), Herder Verlag, Freiburg-Basel-Wien 2002, s. 351; L.T. J o h n s o n, Reading Romans. A Literary and Theological Commentary, Smyth\&Helwys Publishing, Macon 2001, s. 188-191.

J-N. Aletti, (t e n ż e, List do Rzymian, s. 1454n.) przedstawia następującą kompozycję retoryczną sekcji 12,1-15,13. Składa się ona z kilku jednostek retorycznych ze zdaniami rozkazującymi pełniącymi funkcje subpropositiones, po których następują wyjaśnienia lub usprawiedliwienia. Wersety 12,1-2 pełnią funkcję propositio dla całej sekcji, wszystkich zawartych w niej zachęt, które rozłożone są tematycznie w dwóch dłuższych jednostkach retorycznych (12,3 - 13,14 i 14,1 - 15,13), każda zbudowana z kilku mniejszych jednostek z własnymi subpropositiones. Pierwsza sekcja 12,3 - 13,14 dotyczy życia chrześcijan w Kościele i świecie. Składa się ona z sześciu jednostek: 12,3-16 (w. 3 subpropositio) - życie w Kościele to braterski szacunek dla siebie nawzajem, wolny od wywyższania się jednych nad drugimi; 12,17-21 (w. 17 subpropositio) - życie w Kościele to wolność od zemsty w stosunku do wszystkich ludzi; 13,1-7 (w. 1 subpropositio) - życie w Kościele to podporządkowanie wobec zewnętrznej władzy świeckiej; 13,8-10 (w. 8 subpropositio) - życie w Kościele to nade wszystko miłość braterska, która jest wypełnieniem Prawa; 13,11-14 - obecność w Kościele to eschatologiczne ukierunkowanie życia chrześcijańskiego. Druga sekcja 14,1 - 15,13: przypadek słabych - „Niech każdy z nas stara się podobać bliźniemu dla dobra, ku zbudowaniu; przecież Chrystus nie miał upodobania w siebie" (15,2-3). Składa się z następujących jednostek: 14,1 subpropositio dla całej sekcji - „tego, kto jest słaby w wierze, przygarniajcie, bez spierania się o poglądy"; 14,2-23 - przypadek silnych i słabych: różne reguły i zasady rozróżniania. 15,1-13 - chrystologiczne rozwinięcie i motywacja: 15, 1-6 - nie szukać własnej korzyści, lecz naśladować wzór Chrystusa; 15,7-13 - życzliwość wobec innych, tak jak Chrystus okazał nam życzliwość. 15,14-33 - peroratio (zakończenie) całego listu. Por. H. L a n g k a m m e r, List do Rzymian. Pismo Święte Starego i Nowego Testamentu, Wydawnictwo KUL, Lublin 1999, s. 154n.

3 Wprowadzoną propositio 1,16-17 do całego listu. W Liście do Rzymian Paweł stosuje charakterystyczny dla siebie schemat od indykatywu do imperatywu. Indykatyw $(1,16 n$.) - rozwinięcie $(1,18$ - 11,36); Imperatyw $(12,1-2)$ - rozwinięcie $(12,3$ - 15,13). Indykatyw przygotowuje imperatyw, imperatyw zaś jest dopełnieniem indykatywu; wymogiem wiary jest bowiem jej realizacja w chrześcijańskiej egzystencji; por. G. R a fi ń s k i, Rozum jako źródło wartości moralnej czynu 
kilka istotnych pytań, na które należy odpowiedzieć, by właściwie rozpoznać intencje, jakimi kieruje się Paweł, redagując je w takiej właśnie formie i treści. I tak, czy jako centralne przesłanie propositio uważa on zachętę do „rozumnej służby” (logikēn latreian), czy też do „przemiany siebie” przez „odnowienie umysłu” (anakainōsei noos)? Czy „odnowienie umysłu” nie odgrywa jednak, w przedstawionej tu argumentacji, podstawowej roli w nakreślonym przez niego procesie dochodzenia do właściwego rozumienia, na czym ma polegać „rozumna służba”? Czy nie „odnowiony umysł” jest, według niego, kluczowy w tym procesie? Jeśli tak, to należy zapytać o funkcję i znaczenie, jakie przypisuje on „odnowionemu umysłowi” w ,przemienianiu siebie” i kreowaniu „rozumnej służby” Bogu; jak widzi ich wzajemne relacje? I tu ważne, by się dowiedzieć, czym według apostoła ma być „odnowiony umysł”, żeby mógł być zbawczo skutecznym kreatorem tożsamości chrześcijańskiej, przejawiającej się w „przemienianiu siebie” ku „rozumnej służbie” - składaniu sōma „na ofiarę żywą, świętą i miłą Bogu”.

Ostatecznie więc pytamy, co właściwie chciał Paweł powiedzieć adresatom swego listu, zachęcając ich do pełnienia „rozumnej służby", i jak widzi drogę dojścia do niej? Należy też zapytać, jaką funkcję i znaczenie przypisuje tej jednostce argumentacyjnej w jej parakletycznym kontekście sekcji 12,3 - 15,13? Aby udzielić poprawnej i wyczerpującej odpowiedzi na postawione pytania, należy dokonać szczegółowej egzegezy propositio $(12,1-2)$ w jego kontekście retorycznym, co stanowi przedmiot badań naukowych niniejszego studium.

ludzkiego w Liście do Rzymian, w: E. P a c h c i a r e k (red.), Mitość jest z Boga, Wydawnictwo ATK, Warszawa 1997, s. 335-357.

4 Wyrazem „rozumniej służby” ma być składanie „ciała na ofiarę żywą, świętą i miłą Bogu” (12,1). „Odnowa umysłu” zaś ma być przyczyną sprawczą ,przemiany” i ,nonkonformizmu” wobec świata $(12,2)$. 


\section{Kontekst Rz 12,1-2}

Przesłanie sekcji zachęt $\left(12,3\right.$ - 15,13) to parakleza ${ }^{5}$ dotycząca sposobu i stylu życia wyznawców Jezusa wewnątrz wspólnoty Kościoła oraz w jej relacji do świata. Apostoł wprowadza ją ogólną zachętą zredagowaną w formie propositio: „Zachęcam więc was, bracia, ze względu na miłosierdzie Boga, do składania waszego ciała [sōma] na ofiarę żywą, świętą, miłą Bogu, jako wyraz waszej rozumnej [logikēn] służby [latreian]. ${ }^{2}$ I nie dostosowujcie się [mē syschèmatidzesthe] do tego wieku [aiōni], lecz przemieniajcie się [metamorfousthe] przez odnowienie [anakainōsei] umysłu [noos], w celu rozpoznania [eis to dokimadzein] siebie [hymas], co jest wolą Boga, co jest dobre i miłe i doskonałe" $(12,1-2){ }^{6}$

Tymi dwoma zdaniami otwierającymi sekcję 12,1-15,13, zgodnie $\mathrm{z}$ ich retoryczną funkcją, apostoł nadaje konstytutywny sens i fundamentalne znaczenie następującej po nich paraklezie. Zachęca, aby

5 Od greckiego paraklēsis - „zachęta”, „wezwanie”, ,apel”, „pociecha”, „pocieszenie”.

6 Propositio zawiera dwie zachęty: w 12,1 i w 12,2. Pierwszą $(12,1)$ apostoł wprowadza zwrotem parakalō oun (,zachęcam więc”) z bezokolicznikiem parastēsai (,do składania”). Drugą $(12,2)$ buduje z dwóch imperatywów, jeden w sensie negatywnym: mē syschēmatidzesthe („nie dostosowujcie się”), drugi zaś w sensie pozytywnym: alla metamorfousthe („lecz przemieniajcie się”), do którego został dołączony przez eis to (,w celu”) bezokolicznik dokimadzein (,rozpoznania"), podobnie jak w 12,1, które mogą pełnić funkcję okolicznika celu lub skutku. Druga zachęta jest wyraźnie podporządkowana merytorycznie pierwszej, pogłębia jej sens i wskazuje, że jest punktem docelowym przedłożonej tu argumentacji. Por. H. S c h 1 i e r, Der Römerbrief, s. 350n.; H. L a n g k a m m e r, List do Rzymian, s. 55. Uwidacznia się tu zastosowana przez Pawła koncentryczna kompozycja retoryczna ABB'A', gdzie w BB' buduje doktrynalny element przesłania (,,rozumna służba” - „odnowienie umysłu”), natomiast w AA' jego element egzystencjalny („ofiara” - „rozpoznanie”). A - „Zachęcam więc was, bracia, ze względu na miłosierdzie Boga, do składania waszego ciała na ofiarę żywą, świętą, miłą Bogu”. B - ,jako wyraz waszej rozumnej służby”. B' - , ,I nie dostosowujcie się do tego wieku, lecz przemieniajcie się przez odnowienie umysłu”. A' - „w celu rozpoznania siebie, co jest wolą Boga, co jest dobre i miłe i doskonałe". 
całe życie chrześcijanina i całej wspólnoty wierzących, ${ }^{7}$ było głęboko inspirowane i trwale motywowane doświadczeniem miłosierdzia Bożego (,ze względu na miłosierdzie Boga”) w zbawczym dziele Jezusa Chrystusa i darze Ducha Świętego, co obszernie wyłożył w probatio $(1,18-11,36) .{ }^{8}$ Codzienna egzystencja chrześcijan powinna być więc konsekwencją kerygmatu, jego drugą stroną, czyli żywym świadectwem „mocy Ewangelii Bożej”, którą usłyszeli i przyjęli jako program stawania się uczniami Jezusa. ${ }^{9}$ Wyraźnie widać, że Paweł sięga tu do deklaracji z propositio do całego listu o Ewangelii jako „mocy Bożej dla zbawienia wszystkich wierzących” (1,16-17). Kierując się zasadami retoryki, czyni to bez wątpienia w tym celu, by powiedzieć, że należy poddać się jej odnowicielskiej mocy oraz żeby wskazać na konkretnych przykładach, jak owa „moc” powinna przejawiać się w „odnowionym” (anakainōsei) sposobie i stylu życia wierzących w Chrystusa, Syna Bożego. To zaś wszystko dlatego, że dzięki nim ma się ona stawać konsekwentnie mocą przemieniającą również cały „wiek” (aiōn) w którym żyją, czyli doczesność „świata”, w której zostali wezwani przez Boga do dawania o niej autentycznie „żywego, świętego i miłego Bogu” świadectwa „przez składanie $\mathrm{Mu}$ swego ciała [sōma]" w takiej właśnie „ofierze”. To bowiem stanowi najgłębszy sens Bożego wybrania i powołania ich w tym konkretnym eonie -w celu ewangelizacji najpierw siebie a następnie przez siebie świata, w którym żyją jako naśladowcy Boga i Jezusa. ${ }^{10}$

7 Aspekt eklezjalny podkreśla zastosowane tu słowo adelfoi (,bracia”).

8 Wskazuje na to zastosowana partykuła oun (,więc”, ,zatem”); por. H. S c h 1 i e r, Der Römerbrief, s. 351; L.T. J o h n s o n, Reading Romans, s. 188-191; G. R a f i ń s k i, List do Rzymian, s. 349.

9 Por. H. S c h 1 i e r, Der Römerbrief, s. 349. To ich ewangeliczna egzystencja będzie najlepszym świadectwem jej „mocy” działającej w nich. „Moc”, podobnie jak w przypadku Jezusa, jest tym co w sposób fundamentalny odróżnia ją od innych idei religijnych i filozoficznych.

10 Por. J.-N. A 1 e t t i, List do Rzymian, s. 1455; R. J e w e t t, Romans. A Commentary on the Book of Romans, Fortress Press, Minneapolis 2017, s. 724. 


\section{Egzegeza Rz 12,1-2}

Propositio Paweł rozpoczyna czasownikiem parakalō. ${ }^{11} \mathrm{~W}$ swoich listach stosuje go wielokrotnie, jednak w bardzo zróżnicowanych kontekstach, co powoduje trudności w określeniu podstawowego rozumienia przez apostoła jego sensu i znaczenia. ${ }^{12}$ Uwzględniając ten fakt oraz kontekst sekcji 12,1 - 15,13, w której występuje, możemy przyjąć, że chodzi mu w tym przypadku o wyrażenie życzliwej „zachęty”, skierowanej do wiernych Kościoła w Rzymie. Nie wydaje się, by miał on tu pełnić jedynie formalną funkcję figury retorycznej czy też epistolarnej, lecz zdecydowanie widać w nim leżącą mu głęboko na sercu żarliwą troskę wypowiedzianą w formie bardziej ojcowskiej prośby niż paternalistycznego napomnienia czy wręcz nakazu. To również apostolskie dodanie otuchy i zachęta do okazania zdecydowanej odwagi w szczerym i gorliwym podjęciu ewangelicznego przesłania co do sposobu i stylu chrześcijańskiego życia. To wreszcie serdeczne braterskie zaproszenie do okazania ufnego posłuszeństwa Bogu mierzonego wielkością doznanego od Niego miłosierdzia. Zwrócenie się do nich bezpośrednio przez hymas (,was”) i adelfoi (,bracia”) ${ }^{13}$ ten właśnie sens, znaczenie i charakter zachęty apostoła (ojca i brata) wydaje się potwierdzać, jak również odwołanie się do miłosierdzia okazanego przez Boga jemu i im jako grzesznikom, w dziele Jezusa. Nie powinno się zatem doszukiwać w parakalo jedynie zręcznej retoryki czy paternalistycznego moralizmu Pawła, lecz trzeba w nim widzieć przede wszystkim jego pełną miłości Bożej troskę ujętą w formę zachęty, inspirowanej osobistym doświadczeniem ogromu miłosierdzia, którym chce się z nimi dzielić

1 Parakaleō - „zachęcać”, „wzywać”, „prosić”, „błagać”, „zapraszać”, „pobudzać”, ,pocieszać”, „dodawać otuchy”, „dodawać odwagi”, „przywoływać”, „odzywać się życzliwie”.

12 Por. 1Tes 5,11; 5,11.14; 4,1.10.18; 1Kor 14,3.31; 1,10; 16,12; 2 Kor 2,8; 6,1; 8,6; 9,5; 12,18; 8,17; 2,8; 5,20; 12,8; 1,3nn.7; 2,7; 7,4.6n.13; Flm 8nn.; Flp 4,2; Rz 16,12; 15,30; Ef 4,1; L.T. J o h n s o n, Reading Romans, s. 188.

13 Adefoi (,bracia”) pojawia się w innych wprowadzeniach do paraklezy w Listach Pawła (Rz 16,17; 1Kor 1,10; 16,15; 1Tes 4,1.10; 5,14). 
w każdym czasie i przy każdej okazji. Również teraz, gdy pisze do nich list, w przyjętej wobec nich postawie i skierowanym słowie. Jako „Apostoł Ewangelii Boga i Sługa Jezusa Chrystusa” oraz „brat” w Jego Kościele (Rz 1,1-7) pragnie wiernie naśladować miłosierne ojcostwo samego Boga oraz zaświadczyć również przed nimi, że złożył Mu siebie „na ofiarę żywą, świętą i miłą” $(12,1)$ na wzór paschalnej ofiary Jezusa Chrystusa. ${ }^{14}$

Paweł zatem, gdy wzywa chrześcijan Kościoła w Rzymie do „składania ciała na ofiarę żywą, świętą, miłą Bogu" $(12,1){ }^{15}$ jako wyraz „rozumnej służby” z odwołaniem się do „miłosierdzia Bożego”, to tym samym zachęca ich, by postępowali zgodnie z wymogami okazanego im przez Boga miłosierdzia w zbawczym dziele Jezusa i darze Ducha Świętego (Rz 8). Jest ono wypełnieniem Jego odwiecznej woli i nieskończonej miłości wobec grzesznej ludzkości, okazywanej w niezliczonych dziełach zbawczych, o czym pisze w probatio 1,18 - 11,36. Dla apostoła miłosierdzie Boga to fundament, na którym buduje całe swoje nauczanie. ${ }^{16}$ Według niego zbawienie pogrążonej w grzechach ludzkości nie wynika z jakichkolwiek jej zasług - gdyż takich nie było - lecz wypływa z „bogactwa miłosierdzia Boga” (Ef 2,4). Jako „Ojciec miłosierdzia i Bóg wszelkiej pociechy” (2Kor 1,3) nigdy nie opuścił On Izraela, nawet w chwilach jego największej niewierności, by nie dopuścić do zniweczenia misji zbawienia wszystkich narodów powierzonej mu w powołaniu Abrahama. ${ }^{17}$ Nawet wówczas gdy w swej większości wybrany przez Niego lud odrzucił Jezusa, nie cofnął swej łaski (Rz 9-11), lecz otworzył przed nim kolejną szansę na nawrócenie i dostąpienie daru zbawienia, którego doznali już poganie dzięki ich nieposłuszeństwu. Bóg ,poddał

14 Por. R. J e w e t t, Romans, s. 725.

15 Por. M. P e r ro n i, Kerygmat i kult (lektura Rz 12,1-2), w: E. B o r g h i (red.), Czytać Biblię dziś, tłum. J. C h a p s k a, Wydawnictwo „Apostolicum”, Ząbki 2004, s. 56-68.

16 Por. 2Kor 1,3; 6,12; 7,15; Kol 3,12; 2Sm 24,14; 1Krn 21,13; Ne 9,19.27.28.31; Ps 25(24),6; 40(39),12; 51(50),3; Iz 63,15; Pwt 13,18; Flp 2,1.

17 Por. Rdz 12,1-3; Pwt 13,17; Ps 25[24],6; Oz 1,6n.; Ps 69[68],16-18; Iz 30,18; Pwt 30,3; Iz 49-10.13; Jr 12,15; Ez 39,25; Iz 54,8; 55,3; Jr 33, 26. 
wszystkich nieposłuszeństwu" - najpierw pogan, a później Żydów (Rz 9,15-18; 11,32), aby jedni i drudzy w ten sam sposób dostąpili zbawienia. Dzięki zaś posłuszeństwu wierze i oddaniu czci prawdziwemu Bogu przez pogan, również i Żydzi w przyszłości doznają po raz kolejny miłosierdzia wiodącego ostatecznie ku zbawieniu w Chrystusie (Rz 11,28-31). Zastosowany tu argument miłosierdzia Bożego po raz kolejny odsłania towarzyszące apostołowi głębokie przekonanie, że również w relacji do adresatów listu on sam jest jedynie miłosiernym narzędziem Boga. Jak zawsze w jego ,służbie Ewangelii", tak również i w tym spotkaniu z nimi przez słowo, tak naprawdę to nie on zwraca się do nich, lecz sam Bóg przez niego; miłosierdzie Boga dotyka ich za pośrednictwem jego osoby i misji słowa. Chce to im zakomunikować, zanim przejdzie do przedstawienia katalogu zachęt, aby gdy je usłyszą, mieli pełną świadomość, że nie są to jego osobiste zachęty, lecz Boga, któremu służy, przekazując jedynie w niczym niezmienioną Jego wolę, objawioną teraz w Jezusie i darze Ducha Świętego. ${ }^{18}$

$\mathrm{Na}$ zasadę racjonalnej, logicznej i odpowiedzialnej współmierności, mierzonej miarą wyznaczoną przez przyjętą wiarę, Paweł wskazuje ewidentnie w najbliższym subpropositio $(12,3)$, gdzie pisze „stosownie do wiary otrzymanej od Boga”, a następnie, zgodnie z zasadami retoryki, wyraźnie zaznacza to w następnej jednostce retorycznej 12,4-16 i symptomatycznie powraca do niej w kolejnych jednostkach całej sekcji. ${ }^{19}$ Oznacza to, że według niego chrześcijanie, chcąc ,rozumnie żyć” wyznawaną wiarą, muszą oddać się do dyspozycji Bogu całkowicie i bezwarunkowo, stosownie do skierowanej

18 Por. H. S c h 1 i e r, Der Römerbrief, s. 353-355; H. L a n g k a m m e r, List do Rzymian, s. 155; L.T. J o h n s o n, Reading Romans, s. 189; R. J e w e t t, Romans, s. 726 .

19 Na retoryczną kontynuację wskazuje zastosowany w 12,3 spójnik gar - „,bowiem”, ,bo”, ,gdyż”, ,ponieważ”. Aspekt ten wyraźnie implikuje trud intelektualny, racjonalność, logiczność życia chrześcijańskiego. To konstytutywny atrybut osoby ludzkiej jako „obrazu i podobieństwa” Boga; por. G. R a f i ń s k i, Rozum jako źródto wartości moralnej, s. 338n. 
do nich Jego odwiecznej i w niczym nieograniczonej miłości. ${ }^{20}$ Musi to być „ofiara" realna, konkretna i z całego życia oraz pełni osoby ludzkiej w jej duchowo-cielesnej komplementarności i wolnej woli (sōma), egzystującej w konkretnym czasie i przestrzeni. ${ }^{21}$ „Ofiara żywa, święta i miła", ${ }^{22}$ czyli ofiara składana świadomie i dobrowolnie na wzór działania Boga i Jezusa, którego paschalna ofiara jest doskonałym zwieńczeniem nieprzerwanego i niezmiennego Bożego miłosierdzia okazywanego grzesznej ludzkości. Bóg jest taki ze swej istoty i z całego serca, dlatego też ofiarował Jezusa za grzechy ludzkości, ${ }^{23}$ czyniąc Go „,naszą Paschą” złożoną w ofierze „za nasze grzechy” (1Kor 5,7n.). Jego „ustanowił narzędziem przebłagania przez wiarę mocą Jego krwi”. ${ }^{24}$ Chrystus, posłuszny woli swego Ojca, złożył z siebie ofiarę „,doskonałą”, która raz na zawsze gładzi grzechy ludzkości. ${ }^{25}$ Od aktu złożenia Jego paschalnej ofiary nie ma już miejsca dla jakichkolwiek zwyczajowych ofiar typowych dla kultu żydowskiego i pogańskiego. ${ }^{26}$ Odtąd to jedynie od ofiary Jezusa zależy przebaczenie wszelkich grzechów każdego grzesznika. Dlatego też Jego wyznawcy muszą czuć się głęboko zobowiązani do współmiernego naśladowania Go we wszystkim i w całej pełni, być jednocześnie kapłanami i ofiarą, jak On sam. Składać siebie Bogu

20 Por. 1Kor 8,8; 2 Kor 4,14; 11,2; Rz 6,13.16.19; Ef 5,27; Kol 1,22.28.

${ }_{21}$ Por. 2Kor 10,10; 1Kor 15,35nn.; 5,10; 4,10; Ga 6,17; Rz 12,1; 1Kor 7,4; 9,27; 13,3; 6,20. L.J. K r e it z e r, Sōma, w: G.F. H a w th ro n e, R.P. M a r t i n, D.G. R e i d (red.), Słownik Teologii św. Pawła, Wydawnictwo „Vocatio”, Warszawa 2010, s. 124; G. R a f i ń s k i, List do Rzymian, s. 361.

22 Życie chrześcijanina opisuje Paweł terminologią kultyczną. „Ofiara żywa” to ofiara spełniana świadomie i dobrowolnie; por. H. L a n g k a m m e r, List do Rzymian, s. 154n.

23 Por. L. M or ris, Miłosierdzie, w: G.F. H a w th ron e, R.P. Marti n, D.G. R e i d (red.), Stownik Teologii św. Pawła, s. 476; H. L a n g k a m m e r, List do Rzymian, s. 155.

24 Por. Rz 3,25; 8,3.32; 2 Kor 5,21.

25 Por. Ef 5,7; 1Kor 15,20.23; por. H. L a n g k a m m e r, List do Rzymian, s. 156.

26 Odwołanie się do ofiary paschalnej Jezusa pozwala mu na przełamanie tradycyjnej bariery podziału między wymiarem ,świeckim” i „sakralnym” życia chrześcijanina; por. G. R a f i ń s k i, Rozum jako źródło wartości moralnej, s. 344. 
na „ofiarę żywą, święta i miłą” (12,1), to znaczy również na miarę tego, kim stali się w nowej rzeczywistości zbawczej przez wyznanie wiary i chrzest. ${ }^{27}$ Są ,„świętymi” żyjącymi „nowym życiem”, gdyż zostali uświęceni Duchem Świętym i w Nim też „powołani do świętości - doskonałości”. ${ }^{28}$ Jako żyjący już „nowym życiem”, uświęceni i powołani do świętości, muszą stawać się ciągle na nowo miłą Bogu ofiarą. ${ }^{29}$ Ofiarą doskonałą, na miarę tej, jaką stał się Syn dla swojego Ojca. Wszystko zaś to w tym celu, aby wraz z Nim, mocą Ducha Świętego, w sposób bezkompromisowy przezwyciężać grzech w czasie całej ziemskiej egzystencji i nieprzerwanie podtrzymywać w sobie nowe życie w świętości, a tym samym i umiłowanie przez Boga. ${ }^{30}$ Jedynie taka postawa jest godna chrześcijanina żyjącego „nowym życiem”, bowiem jest już zdolny rozpoznać zgodnie z logiką Boga, Jego mądrością i sprawiedliwością, wszystko, co jest Jego wolą na tym etapie dziejów zbawienia (1Kor 2,1-16). ${ }^{31}$

Tak pojmowana „rozumność służby”, realizowanej realnie w konkretnych czynach, to w pierwszym kroku „niedostosowywanie się do tego wieku [aiōni]", ${ }^{32}$ czyli radykalny sprzeciw i bezkompromisowe niepoddawanie się jego wpływom, absolutny nonkonformizm, jakiego żąda prawdziwa wiara w Jezusa i autentyczne życie w Jego

27 Por. Rz 6,1nn.; 8,1nn.12nn.

28 Por. 1Tes 4,7; 2Tes 2,13; 1Kor 6,11; 1,2; Rz 6,22; 1Tes 4,3; 3,13; 5,23.

29 Por. Rz 15,15.

30 Por. L. M or r i s, Ofiara, w: G.F. H a w th ro n e, R.P. M a r t i n, D.G. R e id (red.), Słownik Teologii św. Pawła, s. 555n.; H. S c h 1 i e r, Der Römerbrief, s. 355n.

${ }_{31} \mathrm{Na}$ ów trud intelektualny wskazuje zwrot z 12,2: ,w celu rozpoznania [eis to dokimadzein] siebie, co jest wolą Boga, co jest dobre i miłe i doskonałe"; por. 1Kor 2,1-16; R. J e w e t t, Romans, s. 727-730.

32 „Wiek” (aiōn) w Listach Pawła jest synonimem terminu ,świat” (kosmos); por. 1Kor 1,20; 2,6.8; 3,18n.; 5,9nn.; 7,31nn.; 2Kor 4,4; 1Tm 6,17; 2Tm 4,10; Tt 2,12; Ga 1,4; Ef 1,21; 2,2. „Wiek” i „świat” zawsze reprezentują rozmaite wrogie siły i władze z którymi chrześcijanin musi podejmować radykalną i nieustanną walkę. Nie wolno mu dać się im pokonać i podporządkować; por. L.T. J o h n s o n, Reading Romans, s. 190. 
Kościele. ${ }^{33} \mathrm{~W}$ dalszym kroku to fundamentalne i radykalne, wręcz cudowne ,przemienianie się" (metamorfousthe), ${ }^{34} \mathrm{tj}$. ,zmienianie siebie samego" (sōma). Apostołowi nie chodzi w tym wezwaniu o przemianę ,świata", lecz przede wszystkim samych siebie, po oderwaniu się od tego co światowe. ${ }^{35}$ Nie można bowiem zmieniać innych, jeśli nie jest się najpierw samemu, $w$ głębi jestestwa i egzystencji, przemienionym. Nie chodzi tu też o punktową, jednokrotną przemianę, lecz o stały proces dokonującej się pełnej przemiany, ponieważ „świat” nieustannie kusi i żąda dostosowywania się do niego. Wyznawca Jezusa musi więc trwać w nieprzerwanym procesie ,przemieniania siebie samego", całego siebie w swej duchowo materialnej komplementarności (sōma).

Żeby jednak tak fundamentalne i radykalne przemienianie siebie (sōma) - na miarę okazanego miłosierdzia i sprawiedliwości Bożej w Jezusie - mogło się dokonywać, to musi się to stać przez „odnowienie umysłu” (anakainōsei nous) ${ }^{36}$, gdyż tylko już i nadal

33 Por. 1Kor 4,6; 2Kor 11,13-15; Flp 3,21. A. G i e n i u s z, Boże miłosierdzie jako źródto chrześcijańskiego nonkonformizmu (Rz 12,1-2), Verbum Vitae 3/2003, s. 139-16; t e n ż e, Rz 12,1-8: podstawy chrześcijańskiego nonkonformizmu, Zeszyty Historyczno-Teologiczne. Rocznik Collegium Resurrectionum 6 (2000) nr 6, s. 20-33.

34 Metamorfeomai - „być przemienianym”, „dawać się zmieniać”, „zmieniać się”, ,przekształcać się”, „być przekształcanym”. Poza naszym tekstem termin ten w formie metamorfousthai występuje jeszcze w 2Kor 3,18 i odnosi się do „Ducha Pana”, za którego „sprawą przemieniamy się od chwały do ku chwale w ten sam obraz (chwały Pana)".

35 Dla Pawła jest oczywiste, że stawianie na „świat” (eon) musi zakończyć się przegraną; por. 1Kor 7,31.

36 Nous - „umysł”, „rozum”, „mentalność”, „myśl”, „,myślenie”, ,zamysł”, „,sposób myślenia”, „umysłowość”. Anakainōsis - „uczynienie nowym”, „odnowienie”. Anakainoō - „czynić nowym”, „odnawiać”. Zwrot metamorfousthe tē anakainōsei tou noos można też przetłumaczyć: ,przemieniajcie się w odnowionym umyśle/ odnowieniu umysłu".

W Rz termin nous pojawia się jeszcze sześciokrotnie. W 1,20.28 chodzi o rozum naturalny jako jakość intelektualną i poznawczą, którą dysponowali poganie. Okazała się jednak w ich przypadku bezużyteczna w poznaniu Boga i usprawiedliwienia w Jezusie. W 7,23.25 nous jawi się jako intelektualna jakość poznawcza powiązana z Bogiem i przeciwstawna sferze życia podległej grzechowi. Jest to 
trwale „odnawiany umysł” będzie w stanie „rozpoznawać” i dogłębnie w całości „poznawać [eis dokimadzein] wolę Boga [ti to thelema tou theou ]". ${ }^{37}$ Nie ulega wątpliwości, po tym, co wyłożył Paweł w probatio listu, że tylko umysł odnawiany nieustannie Ewangelią objawianą w Jezusie i darze Ducha Świętego pozna pełną wolę Boga, która ma swój realny i konkretny wyraz w tym, co jest „dobre i miłe i doskonałe" $(12,2)$ w rozumieniu mądrości i sprawiedliwości Bożej, a nie „światowej”. ${ }^{38}$ Zatem tam, gdzie będą realizowane wymienione atrybuty „woli”, tam będzie wypełniać się również ona sama, tam będzie obecny Bóg ze swoim miłosierdziem i zbawieniem. ${ }^{39}$ Tak rozpoznaną rzeczywistość zbawczą, zdaniem apostoła, można będzie prawidłowo rozumieć w podlegającym nieustannym zmianom doczesnym eonie, jedynie dzięki trwale „odnawianemu umysłowi [nous] wolą Bożą”, to znaczy „Ewangelią” oraz mocą „Ducha Bożego i Chrystusowego", który uświęca i wiedzie ku świętości (Rz 8,1-39). „Dobroć, miłość i doskonałość” muszą więc na stałe stać się fundamentalnymi i niezbywalnymi wektorami znaczącymi

sfera w człowieku podatna na natchnienia Boga, zatem człowiek, poddając swój umysł Jego natchnieniom, będzie w stanie Mu służyć. Cały rozdział ósmy wyjaśnia proces i skutki odnowy umysłu „,człowieka wewnętrznego” przez Ducha Świętego. W 11,34 pojawia się w cytacie z Iz 40,13 i odnosi się do Boga. Z treści listu wynika, że tylko Jezus poznał „sposób myślenia” Pana (nous) - wolę Boga, którą to objawił On w Ewangelii, teraz zaś czyni to Paweł. W 14,15 apostoł zachęca do szukania „umocnienia” w zgodności ze „sposobem myślenia” (nous) odnowionym przez Ewangelię i Ducha Świętego, jeśli chcą pozostać wierni Bogu w swym postępowaniu; por. G. R a f i ń s k i, Rozum jako źródto wartości moralnej, s. 339-341.

Anakainōsis występuje jeszcze w Tt 3,5, gdzie apostoł odnosi go do Ducha Świętego jako podmiotu odnawiającego chrześcijanina. W formie anakainousthai występuje jeszcze dwukrotnie. W 2Kor 4,14 odnosi się do „człowieka wewnętrznego”, który „odnawia się z dnia na dzień w blasku Ewangelii chwały Chrystusa, który jest obrazem Boga” (4,4). W Kol 3,10 również odnosi się do „człowieka wewnętrznego”, który jest „odnawiany na obraz swojego Stwórcy, aby Go poznać”.

37 Por. Rz 1,28; 14,22; Flp 1,10; Ef 5,10.

38 Por. 1Kor 2,1-16; 1Tes 4,3; 5,16-18.

39 Por. Flp 4,8n.

40 Por. 1Kor 1,1-9. 
drogę w naśladowaniu miłosierdzia Boga i paschalnej ofiary Jezusa w chrześcijańskiej egzystencji. ${ }^{41}$

Apostoł, zwracając się do braci w Rzymie w pierwszej osobie (,zachęcam”), wskazuje na siebie jako na najbardziej właściwego i w pełni wiarygodnego świadka ,przemiany” i „służby”, do jakiej ich zachęca. To on, jako wróg Jezusa i prześladowca Jego Kościoła, na skutek doznanego od Boga miłosierdzia, „odnowił umysł” objawioną mu nową ,wolą Bożą" w wydarzeniu pod Damaszkiem ${ }^{42}$ i od tego momentu oddał się we wszystkim na „służbę” Bogu w Jego Synu jako „nowe stworzenie", ${ }^{43}$ o czym daje teraz świadectwo jako prawy apostoł $(9,1) .{ }^{44}$ Jest absolutnie przekonany, że podobnie jak w jego przypadku, to jedynie poznanie woli objawionej w Ewangelii ${ }^{45}$ oraz dzięki mocy Ducha Świętego pozwoli im właściwie rozpoznać siebie, swój aktualny status zbawczy oraz stopień zaangażowania w świadectwo wiary wobec świata, w którym żyją, czyniąc wyłącznie w nim to, „co jest dobre, miłe i doskonałe” $(12,2)$ w ocenie mądrości i sprawiedliwości Bożej, jako wyraz racjonalnej logicznej, adekwatnej, godnej osoby ludzkiej odpowiedzi na okazane miłosierdzie w paschalnej ofierze Jezusa. ${ }^{46}$

41 Por. Rz 12,9.21; Ga 6,10; 1Tes 5,15; Flm 6; Flp 4,12.15; Ef 6,8; 5,10; Kol 1,28; 3,14; L.T. J o h n s o n, Reading Romans, s. 191; R. J e w e t t, Romans, s. 732.

${ }^{42}$ Por. Dz 9,1-19.

43 Por. Rz 9,4. Tylko tu Paweł stosuje po raz drugi termin latreia - „służba Boża”, „cześć Boga”. Latreuō - „oddawać cześć”, „,sprawować kult”, „być sługą”, „służyć”. O nowym narodzeniu Pawła w wydarzeniu pod Damaszkiem mówią Dz 9,9.17-19 przez symboliczne nawiązanie do trzech dni proroka Jonasza i przebywania w grobie Jezusa oraz odzyskanie nowego życia mocą Ducha Świętego w chrzcie.

44 Por. Dz 9,1-9; 1Tm 1,12-16. Pełni posługę zleconą mu przez miłosierdzie (2Kor 4,1) i dzięki niemu godzien jest, aby mu wierzono (1Kor 7,25).

45 Por. 2Kor 11,10.

46 Por. H. S c h 1 i e r, Der Römerbrief, s. 358-362; L. T. J o h n s o n, Reading Romans, s. 191; R. J e w e t t, Romans, s. 732-734; G. R a fi í s k i, Rozum jakoźródto wartości moralnej, s. 335-357; A. G i e n i u s z, Boże miłosierdzie, s. 139-161. 


\section{Ku „rozumnej służbie” przez „odnowienie umysłu Ewangelią"}

Na „rozumną służbę” Bogu, jako centralną ideę kerygmatycznego przesłania propositio, na której apostoł buduje paraklezę sekcji 12,3 15,13, wyraźnie wskazuje już zastosowana przez niego kompozycja retoryczna, gdzie werset 12,2 merytorycznie podporządkowuje 12,1. Odwołaniem zaś do „miłosierdzia Boga” sugeruje, że według niego taka właśnie służba jest jedyną godną chrześcijan odpowiedzią na okazane im miłosierdzie w dziele zbawczym dokonanym w Jezusie. ${ }^{47}$ Drogę wiodącą do niej widzi następująco. Po pierwsze - polega ona na „niedostosowywaniu się” do tego „świata”, „składaniu samego siebie [sōma] na ofiarę żywą, świętą i miłą Bogu" $(12,1)$. Po drugie - na „przemianie” całej osoby ludzkiej (sōma) przez „odnowienie umysłu", gdyż jedynie taki umysł jest w stanie rozpoznać zbawczy status własnej osoby (siebie) oraz wolę Boga, to, co jest według niej „dobre, miłe i doskonałe” $(12,2)$.

W radykalnym i fundamentalnym ,przemienianiu siebie samego" (sōma) nie chodzi o pojedynczy akt, lecz o ustawiczny proces dokonującej się wręcz transsubstancjacji sōma, ponieważ również „świat” nieprzerwanie się zmienia i żąda nieustannego dostosowywania się do niego w każdym jego przejawie i wymiarze. Paweł, mówiąc o tym, niewątpliwie odnosi się do jednej z najważniejszych dla niego idei, a mianowicie ,nowego narodzenia”, „nowego stworzenia”, ${ }^{8}$ jakie dokonuje się przez poznanie Ewangelii, wyznanie wiary w Jezusa, chrzest i dar Ducha Świętego. W ten sposób chrześcijanin staje się „obrazem” (eikōn) Chrystusa, ${ }^{49}$ zyskuje „sposób myślenia”, „umysł Chrystusa" (nous Xristou), ${ }^{50}$ co w konsekwencji musi znaleźć swe odzwierciedlenie w codziennej egzystencji; chrześcijanie bowiem

47 Por. 1Kor $1-4$.

48 Por. Tt 3,5; 2 Kor 4,16; 5,17; Ga 6,15; Rz 6,4; 8,2.

49 Por. Kol 3,16; Tt 3,5; 2 Kor 4,16; por. H. L a n g k a m m e r, List do Rzymian, s. 157.

50 Por. 1Kor 2,16; L. T. J o h n s o n, Reading Romans, s. 190; R. J e w e t t, Romans, s. 731n. 
„zostali uświęceni w Chrystusie Jezusie” i Duchu Świętym oraz „powołani do świętości” (1Kor 1,1-9).

Taka „przemiana siebie [sōma] w ofiarę żywą, świętą i miłą Bogu”, jako wyraz rozumnej Mu służby, staje się możliwa jedynie przez „odnowienie umysłu” (nous). Tylko bowiem odnowiony Ewangelią umysł jest w stanie rozpoznać i zgłębić aktualną wolę Boga, która rozstrzyga co na obecnym etapie dziejów zbawienia jest dobre i doskonałe, a tym samym miłe Bogu oraz pozwala poznać człowiekowi żyjącemu w tym eonie swój prawdziwy status zbawczy, widziany w świetle mądrości i sprawiedliwości Bożej. W obecnym eschatonie zbawczym Bóg objawia swą wolę w Ewangelii, która ,jest mocą zbawczą dla każdego wierzącego" (Rz 1,16), czyli w osobie i dziele Chrystusa oraz darze Ducha Świętego, którzy w Kościele dokonują swą mocą odnowy i przemiany grzeszników, obdarowują ich nous Xristou (Rz 8,1-39). ${ }^{51}$ To dlatego można mówić o transsubstancjacji sōma; ofiara spalana zmienia nie tylko formę ale i substancję, dlatego też „dobroć, miłość i doskonałośćc” jako atrybuty „,nowego stworzenia", muszą stanowić fundamentalne i niezbywalne wartości znaczące drogę w naśladowaniu Boga i Jezusa dla chrześcijańskiej wiary i egzystencji, ponieważ takimi pozostają w zbawczym działaniu Chrystusa zmartwychwstałego i Ducha Świętego w Kościele, a przez niego w świecie, niosąc w sobie odnowicielską moc „,nowego stworzenia" - przemienionego, zmartwychwstałego. ${ }^{52}$ To zaś oznacza konieczność trwałego i ustawicznego odcinania się od wpływów tego świata przez czynienie tego, co jest ,święte, doskonałe i miłe Bogu” oraz składanie wszystkich skutków takiego działania wraz z całym sobą (sōma) w ofierze na wzór ,żywej, świętej i miłej Bogu” ofiary paschalnej Jezusa, który jako pierwszy przeszedł drogę poznania woli Ojca oraz przemiany w śmierci i zmartwychwstaniu.

Mając na uwadze powyższe analizy i wnioski, można zasadnie przyjąć, że według Pawła, nous nieustannie, objawioną w tym

51 Por. 1 Kor $1,1-9$.

52 Por. Rz 12,9.21; Ga 6,10; 1Tes 5,15; Flm 6; Flp 4,12.15; Ef 6,8; 5,10; Kol 1,28; 3,14 . 
eschatonie w całej pełni i prawdzie w osobie i zbawczym dziele Jezusa oraz w darze Ducha Świętego, teraz zaś głoszoną przez niego w Ewangelii, to prawdziwie jedyny godny Bożego miłosierdzia i skuteczny zbawczo sposób na przemianę całej osoby ludzkiej (sōma). Owa zaś przemiana to jedyna droga wiodąca do pełnienia „,rozumnej służby”, gdyż chrześcijanin, poznawszy w pełni wolę Boga przez przyjęcie Ewangelii, racjonalnie, dojrzale intelektualnie i duchowo, godnie „nowego stworzenia”, świadom okazanego mu miłosierdzia „stosownie do otrzymanej wiary od Boga" $(12,3)$ - odpowiada na nią całym sobą i pełnym swym życiem tak, jak Bóg tego od niego oczekuje, czyli „służy” Mu na wzór Jezusa Chrystusa, składając Mu siebie w ofierze paschalnej. Ostatecznie więc, ,rozumna służba” to dla apostoła „ewangeliczna służba”, to uzewnętrznienie miłosierdzia Bożego w świecie. Trwale odnawiany Ewangelią i mocą Ducha Świętego umysł to również absolutny warunek stałej przemiany siebie (sōma) w ofiarę ,żywą, świętą i miłą Bogu”. Tak ,odnawiany umysł", jest też nie tylko w pełni wiarygodnym gwarantem rozeznania i dogłębnego poznania, na czym polega „rozumna służba”, ale i na zachowanie tego poznania od zniekształcenia przez wpływy świata.

ks. Zdzisław ŻYWICA

Słowa kluczowe: miłosierdzie, ofiara, rozumna służba, przemiana, odnowiony umysł, wola Boża, Ewangelia

Keywords: mercy, sacrifice, reasonable service, transformation, renewed mind, God's will, Gospel

\section{Reasonable service and a renewed mind in the light of Rom 12,1-2}

\section{Summary}

Exegetical analysis of propositio 12,1-2 and its rhetorical context allows us to conclude that the overriding message is an encouragement to render "a reasonable service to God". According to Paul, it relies on the constant and absolute faithfulness of his will to sacrifice "himself" (sōma) in "a living, sacred and pleasant sacrifice", that is, 
to the measure of the sinful humanity of mercy in the salvific work of Jesus; "according to the faith received from God" $(12,3)$. For the Apostle, the constantly "renewed mind with the Gospel" and the power of the Holy Spirit is an absolute condition to fully know God's will, "transform oneself" (sōma) and save it redemptive effectively through God's "goodness, perfection and love". It is obvious to him that only a man implanted in Christ through the Gospel, baptism and the Holy Spirit becomes his "image" also in the way of thinking (the mind), therefore he is able to constantly re-explore the sense of "reasonable service" to finally find out that it is "evangelical service" in the power of the Holy Spirit, modeled on Jesus himself. This is the only rationally mature (according to the wisdom and justice of God) and worth of a "new creature" (Christian) the answer to God for the work of salvation made in Christ, who sacrificed himself to God in the Passover as a sacrifice of the "good, perfect, living holy and the kind". 